\title{
The US Cap and Trade Initiative: Current Status and Potential Impact on Business
}

\author{
Bruce W. McClain \\ Cleveland State University, b.mcclain@csuohio.edu \\ Heidi H. Meier \\ Cleveland State University, h.meier@csuohio.edu
}

Follow this and additional works at: https://engagedscholarship.csuohio.edu/bus_facpub

Part of the International Business Commons

How does access to this work benefit you? Let us know!

Publisher's Statement

This article is (c) Emerald Group Publishing and permission has been granted for this version to appear here: http://www.emeraldinsight.com/doi/abs/10.1108/19355181311314743. Emerald does not grant permission for this article to be further copied/distributed or hosted elsewhere without the express permission from Emerald Group Publishing Limited.

\section{Original Published Citation}

McClain, B. W., Meier, H. (2013). The US Cap and Trade Initiative: Current Status and Potential Impact on Business. American Journal of Business, 28(1), pp. 7-18.

This Article is brought to you for free and open access by the Monte Ahuja College of Business at EngagedScholarship@CSU. It has been accepted for inclusion in Business Faculty Publications by an authorized administrator of EngagedScholarship@CSU. For more information, please contact library.es@csuohio.edu. 


\title{
The US cap and trade initiative: current status and potential impact on business
}

\author{
Bruce W. McClain and Heidi Hylton Meier \\ Department of Accounting, Cleveland State University, Cleveland, Ohio, USA
}

\begin{abstract} to explain cap and trade and to project what form current proposals could take. actual mechanics by which the system is expected to operate. renewable energy resources. examination of the actual mechanics by which the system is expected to operate

Keywords Cap and trade, US policy on greenhouse gas emissions limits,

Cap and trade effect on US business, United States of America, Energy

Paper type Research paper
\end{abstract}

Purpose - Even during these tough economic times the current administration has proposed to revive the US "Cap and Trade" initiative and to see it through to passage. Many in the public are not aware that the idea of cap and trade is not new as similar programs have been successfully used in the uS and other countries to "wind down" environmentally damaging emissions. The aim of this paper is

Design/methodology/approach - This paper explains cap and trade and goes on to project what form current proposals could take. It also examines the alternatives and the arguments both for and against cap and trade. Projected costs and benefits are examined, along with some examination of the

Findings - The current US mood is that proposals to reduce greenhouse gas emissions will be expensive and burdensome to businesses and consumers. In fact, this is what is preventing them from going forward. The consensus is now growing that in order to achieve the goals of cap and trade, proposals will have to be cost effective, expanded internationally, and include India, China and other emerging manufacturing economies. If this can be done, it appears that cap and trade will continue to be part of the landscape of US emission reductions, along with the use of alternative and other

Originality/value - The paper examines costs and benefits of cap and trade, along with some

\section{Introduction}

Even during tough economic times with record-setting prices for gasoline and energy, the Obama Administration proposed to revive the US "cap and trade" initiative and with the recent elections, is expected to actively pursue this regulation. The latest effort to institute this policy as proposed by Lisa P. Jackson, administrator of the (Environmental Protection Agency (EPA, 2012)) to limit carbon dioxide emissions from new power plants would present major obstacles for coal-fired power plants (Barringer, 2012). Many in the public are not aware that the idea of cap and trade is not new. Similar programs have already been successfully used in the USA and other countries to "wind down" various environmentally damaging emissions. Notable in this regard was America's Clean Air Act of 1990, which focused on sulfur emissions, shown to cause high sulfuric acid content "acid rain." By 2005 that program had achieved significant reductions in sulfur emissions at a relatively favorable cost. This paper explains cap and trade, and goes on to project what form current proposals could take. It also examines the alternatives and the arguments both for and against cap and trade, and what particular costs concern the large part of Americans who continue to question the wisdom 
of pursuing this widespread initiative which some claim will be prohibitively expensive. Both projected costs and benefits are examined, along with some examination of the actual mechanics by which the system is expected to operate.

\section{Description and goals of cap and trade}

Cap and trade (more formally known as emissions trading) attempts to use a market-based approach to encourage the reduction of carbon emissions. The idea is to set a maximum amount allowed for all emissions for various forms of carbon-based energy, such as oil, coal and gas, and then to allow companies to sell or trade their allowed allotments. The goal of an effective emissions trading system is that, by reducing emissions of carbon dioxide, sulfur and other pollutants through the burning of carbon fuels, the company will both reduce its operating costs, and might also actually make money by selling excess credits that are not needed. At the same time, greenhouse gas emissions from fossil fuels are first capped and then reduced over time as the emissions caps are progressively lowered.

Once enacted, the first step in a cap-and-trade system is for the government to place a limit on the total allowable emissions for the various forms of carbon energy. The various users of carbon-based energy, most notably power plants, but also large manufacturing companies, will then be issued a number of permits, or credits, that set the total amount of carbon energy emissions allowed for each permit holder. The idea is that the total carbon fuel emissions for the country would thus be "capped" by the amount of permits or credits issued.If a company needs to burn additional fossil fuels, it would need to purchase credits from another company, one which had been able to reduce its fossil fuel use, and thus to have generated excess credits for sale (Tietenberg, 2003).

Hence, cap and trade seeks to slowly wean the country from its heavy reliance on fossil fuels, using market forces combined with government caps. It sets a maximum for fossil fuel emissions, principally carbon dioxide and sulfur emissions, but also other harmful emissions byproducts, while sinultaneously encouraging companies with the help of market forces, to voluntarily embark on programs to reduce their carbon fuel emissions. Note that the reduction can come either from the reduced use of fossil fuels, or alternatively from the expanded use of clean burning technologies and scrubbers designed to burn the fuels more efficiently or to better capture the harmful elements of the emissions (Jaffe et al., 2009).

In order to further push the process of reducing harmful carbon fuel emissions, there is an additional aspect to the emissions trading initiative. The government also proposes to steadily reduce, or tighten, the caps over time. The original goal for this particular round of cap-and-trade legislation was "to limit the rise in global temperature to approximately $2.0^{\circ} \mathrm{C}\left(3.6^{\circ} \mathrm{F}\right)$ above pre-industrial levels by 2050 by reducing carbon dioxide and other emissions" (Center for American Progress, 2008). This was to be accomplished by setting a cap (representing the original "cap" in the component phrase) in the USA that would be steadily tightened until emissions would be 80 percent below 1990 levels of carbon dioxide gasses by the 2050 deadline. The permits would be auctioned by the government, originally thought to sell in the range of $\$ 10-\$ 15$ per metric ton of carbon dioxide (Center for American Progress, 2008).

A large and dependable revenue stream can actually be created by the federal government through the auction of emission permits to companies that are required to reduce their emissions. This could be very profitable for the government, while at the 
same time, the program would be used to achieve public policy objectives related to climate control and economic development. For companies not able to meet their emission reduction, and which need to purchase allowances from another company, the cost of those additional permits would be determined by the marketplace, depending upon how efficient companies were in managing their emissions and meeting the goals. Profits from the program would accrue to the federal government. Some estimates from the Congressional Budget Office were from $\$ 50$ billion to as high as $\$ 300$ billion per year, with the revenue to be allocated in the following manner: 10 percent of this revenue was for affected industries and their shareholders; half of the remaining revenue to assist low-income families as we shift to more efficient energy sources; and the remaining revenue would be for the development of renewable energy sources, green-collar jobs, and the transition to a low-carbon economy (Broder, 2009).

One sticking point that has garnered a large amount of media attention, and also has helped to undermine support for the emissions trading initiative in the USA and other modern industrialized countries, has been the resistance of the emerging industrial powerhouse economies, notably India and China, to go along with any reasonable version of a cap and trade system. Basically, these carbon-based manufacturing economies rely very heavily on coal (especially China) and already seriously lag their Western counterparts in emission controls or other clean energy efforts, and are fighting the enactment of a cap-and-trade initiative. They see it as an essentially Western-driven, prohibitively expensive luxury that they cannot afford as they seek to raise their citizens' standard of living to one comparable to that of the residents of Western industrialized countries (Kanter, 2010).

\section{History and experience to date}

Cap and trade is not an idea born in the USA. In fact this has been a worldwide phenomenon, both in terms of the initial studies suggesting the need for such an initiative, and also in terms of the original idea of cap and trade itself. Other modern Western nations are not only also looking hard at cap and trade, but in many cases have already gone beyond the USA in their research of cap and trade and in the steps they are taking toward initiating cap-and-trade systems.

In 1988, the United Nations and the World Meteorological Organization created the Intergovernmental Panel on Climate Change (IPCC) to study the effects of what was perceived as developing changes in the global climate (Houghton et al, 1997). The IPCC particularly looked at the effect of greenhouse gases and studied whether an increase in greenhouse gases was changing the global climate, and if it was, what role human activities appeared to play in any increase in greenhouse gases present in the atmosphere. In a series of several reports beginning in the early 1990s, the IPCC concluded that human activities for many years had been increasing the amounts of certain greenhouse gases in the atmosphere, including carbon dioxide, methane and chlorofluorocarbons, or CFCs. These reports further opined that such increases were contributing to the warming of the Earth's surface. Finally, the IPCC concluded that increases in carbon dioxide in the Earth's atmosphere were primarily due to the extensive use of fossil fuels, and also, to some extent from the increasing industrialization and farming of available land, along with modern farming practices including the use of nitrous oxide as a fertilizer (Houghton et al., 1997). 
In fact, it was early policy recommendations from the IPCC which really formed the genesis of the emissions limits and prompted cap-and-trade initiatives in this area. As early as 1995 the IPCC was recommending programs to limit the maximum amount of greenhouse gas and suggested the incorporation of a permit system with the use of market forces to encourage carbon fuel users to reduce emissions. Essentially it was these IPCC studies and recommendations that placed the USA and other major industrialized nations on course to consider the emissions trading proposals that are being seriously debated today (Houghton et al., 1997).

In the case of the USA, there is actually a predecessor example for cap and trade that has been part of US law for some time. A cap-and-trade program that is really not all that different in principle (although much more limited) from what is currently being proposed has actually been in place in the USA since 1990. This was introduced in the Clean Air Act of 1990. According to the (EPA, 2010), the Clean Air Act established a goal to reduce annual sulfur dioxide emissions by 10 million tons below 1980 levels. In order to accomplish this, the law required a two-phase tightening of the restrictions placed on fossil fuel-fired power plants. The first phase began in 1995 and was directed primarily at coal-burning electric utility plants located in 21 Eastern and mid-Western states. In that first year, emissions of sulfur dioxide were reduced by almost 40 percent below the EPA required level. The second phase began in 2000 at which time the annual emissions limits were tightened on large, higher emitting plants and the EPA also began setting limits on smaller and other types of plants. At that time, the law also required that limits to reduce nitrogen oxides be imposed, as well.

The Clean Air Act of 1990 was enacted during the presidency of George H.W. Bush as a response to the outcry from environmentalists and the damage that was being done by acid rain. The Bush administration, campaigning to establish him as the "environmental president" adopted the idea of emissions or allowance trading which later became the foundation for cap and trade (Greenblatt, 2010). During the 1980s, the debate was over acid rain. Today, it is over climate change or global warming. The US Acid Rain Program was viewed around the world as a prototype for tracking emerging environmental issues. According to the EPA, the allowance trading system capitalizes on the power of the marketplace to reduce sulfur dioxide emissions in the most cost-effective manner possible.

Just as with the currently proposed emissions trading program, the 1990 Clean Air Act program included allowances that may be bought, sold or banked; and while anyone may acquire these allowances and participate in the market, no one may emit at levels that would violate federal or state levels. The EPA instituted an electronic recordkeeping system to track allowances and holds an annual allowance auction. Coupled with this is the continuous emissions monitoring and reporting systems that provide accurate accounting of emissions as well as excess emissions penalties that provide incentives for self-enforcement. All of these components contribute to an "integrated program that lets market incentives do the work to achieve cost-effective emissions reductions." The US General Accounting Office confirmed the benefits of this approach, projecting that the allowance trading system could save as much as $\$ 3$ billion per year-over 50 percent-compared with a command and control approach typical of previous environmental protection programs (EPA-Acid Rain Program).

In more recent years however, cap-and-trade initiatives in the USA have been received with growing skepticism if not outright resentment in some circles. This was 
recently exemplified in the midst of the 2010 US elections, when the Democratic governor of West Virginia, a heavy coal mining state, ran a campaign ad in which he seriously criticized the Obama Administration's cap-and-trade initiatives, and then picked up and fired a high powered rifle, expertly placing a shot right through a current US cap-and-trade bill pinned against a post. The significance is that in the USA it has generally been Democrats that have championed cap and trade, and the Republicans that have generally viewed it with more skepticism. Thus, the efforts of a Democrat governor (albeit from a key coal mining state) to not only distance himself from cap and trade, but to demonstrate open antagonism towards it, exemplifies the current skepticism with the policy.

This cautious attitude in the USA towards cap and trade is also demonstrated by US objections to the Kyoto Protocol. The idea of the Kyoto Protocol was to function as an international agreement among major industrialized nations to cap their greenhouse gas emissions. The Kyoto Protocol is an international treaty, initially intended to be effective in 2005. By adopting it, those nations agreed to legally binding emissions targets regarding six major greenhouse gases (Kyoto Protocol, 2012). The Kyoto Protocol divided the nations into annexes or groups, and the USA and other modern industrialized countries were placed into Annex I. Interestingly, the USA was the only industrialized nation under Annex I that did not ratify the treaty. The US Senate refused to ratify the treaty, citing a likely negative effect on the US economy, in particular, and the fact that the growing powerhouse industrial nations, particularly India and China, were not required to comply with the standards.

This refusal to sign on to the Kyoto Protocol continued under the administration of George W. Bush. However, upon the election of President Obama, it was widely expected that there would be a quick change in the USA. It was expected that not only would the Obama Administration, backed by a heavily Democrat-controlled Congress, quickly sign on to the Kyoto Protocol, but that a Kyoto style emissions trading program would soon follow. Instead the Obama Administration came back to suggest major changes to the Kyoto emissions management system that many commentators in other industrialized countries feel that, if adopted, would essentially destroy the present Kyoto Protocol and require the development of an entirely new international agreement to limit greenhouse gas emissions (Hayward et al., 2009). The USA continues to point out that the failure to include major developing economies in the limitation of greenhouse gases both destroys the efficacy of the agreement, and gives such growing economies a fundamental advantage over their more modern counterparts, an added advantage to that which already exists in terms of their much lower labor costs.

\section{Current US proposals}

In June 2009, the US House of Representatives passed the Waxman-Markey climate bill by a vote of 219 to 212. It was a historical move as it was the first time the US Congress had taken steps to address global warming and try to change the way the USA would produce and use energy. At the center of this legislation was a mechanism to establish a cap-and-trade system that would set:

[.. . ] a limit on overall emissions of heat-trapping gasses while allowing utilities, manufacturers and other emitters to trade pollution permits, or allowances, among themselves. The cap would grow tighter over the years, pushing up the price of emissions and presumably driving the industry to find cleaner ways of making energy (Broder, 2009). 
The victory in the House of Representatives was in actuality a compromise, with 44 Democrats voting against the bill and eight Republicans voting in favor. The bill presented standards that were far less stringent than what many European governments wanted and revealed a division between Democrats from non-energy producing states vs those from coal-producing states.

However, the story was quite different for the proposed Lieberman-Graham-Kerry bill in the US Senate. The three senators spent months negotiating a bill that was decidedly less ambitious than the one passed by the house, and only 60 votes were required to pass. However, before it came to the floor for a vote, Senator Graham (R-SC) pulled his support, citing partisan politics and the fact that he had not been able to win over any other Republican co-sponsors (Greenblatt, 2010). The Senate bill was a much narrower version of the cap-and-trade model, one that would only apply to power plants and not to the emissions of vehicles and factories. However, with Graham no longer being a co-sponsor to the bill, and the other important issues facing the Congress, it would appear that climate change legislation has been temporarily tabled.

It is interesting to note that the Republicans are credited with creating the highly successful idea of "cap and trade" as George H.W. Bush was President when The Clean Air Act of 1990 was passed and which has been effective in curbing the effects of acid rain, but are now credited with defeating the latest round of cap and trade. What could have happened in the last round of legislation that made it so unpopular to back this same type of market-based proposal?

It would appear some of the confusion may have started with the authors of the bill themselves as Senator John Kerry (D-Massachusetts) was quoted in 2009 saying "I don't know what 'cap and trade' means" (Kanter, 2010). It was also at this time that the Tea Party was in the limelight and labeled these proposals "cap and tax" (Broder, 2010). In addition, it did not help that the economy was very weak and that some of the proposals gave concessions to various industries which began to look like "tax and redistribution schemes" (Broder, 2010). Following this, Senator Graham (R-SC) pronounced that type of legislation as being. dead in the Senate with the new proposal containing a cap on greenhouse emissions, but now also including new taxes on gasoline and fuels and incentives for other types of energy. Soon this proposal became re-branded as "cap and tax" (Greenblatt, 2010) and given the weak economy, the troubles on Wall Street, and the strong lobby from the energy industry, it was doomed from the start.

Congress today continues to consider competing proposals for emissions trading as outlined in Table I. While the 2009 defeat of cap-and-trade legislation in the US Congress was a setback, the issue is far from dead, and continues to be hotly contested in the USA. Basically, the current proposals being considered can be divided into two groups. One group, the Bingaman - Specter and the Udall - Petri bills, proposes to set the emissions trading overall limits somewhat near current levels. However, another set of bills, sponsored by such notable legislators as Al Lieberman, John McCain, Barbara Boxer and Henry Waxman, are more aggressive (Resources for the Future Foundation, 2012). Table I describes all of these bills and lists them from the least aggressive to the most with regard to the levels of reductions in greenhouse gas emissions (presented in terms of bmt, or billion metric tons, where one metric ton is equal to $£ 2,200$ and one bmt is equal to a billion compact cars) and with proposed reductions ranging from 50 to 80 percent below 1990 levels. This table also presents the proposed allowance prices for $\mathrm{CO}_{2}$-e $\left(\mathrm{CO}_{2}\right.$ and $\mathrm{CO}_{2}$ equivalents) which represents a tax increase from $\$ 2,015$ to $\$ 2,050$ and 


\begin{tabular}{|c|c|c|c|c|c|}
\hline Proposed Bill & Allowance path & $\begin{array}{r}C O \\
\text { price } \\
2015\end{array}$ & $\begin{array}{l}\mathrm{O}_{2}-\mathrm{e} \\
\mathrm{e}(\$ / \mathrm{T}) \\
2050\end{array}$ & Summary & \\
\hline $\begin{array}{l}\text { Bingaman-Specter } \\
\text { Braft (2007) }\end{array}$ & $306 \mathrm{bmt}$ & 7 & 39 & $\begin{array}{l}\text { Requires a reduction in emissions of } \\
60 \text { percent below } 2006 \text { levels by } 2050\end{array}$ & \\
\hline Udall-Petri (2006) & $293 \mathrm{bmt}$ & & & Similar to Bingaman-Specter & \\
\hline $\begin{array}{l}\text { Lieberman-McCain } \\
(2007) \\
\end{array}$ & $\begin{array}{l}203 \text { bmt SEC } \\
\text { (with sectoral } \\
\text { policies) }\end{array}$ & 31 & 121 & $\begin{array}{l}\text { Even though national emissions allowed } \\
\text { estimated at } 216 \text { bmt, costs would be } \\
\text { slightly lower and emissions would be } \\
\text { reduced to } 60 \text { percent of those below } 1990 \\
\text { levels by } 2050\end{array}$ & \\
\hline Feinstein (2006) & $203 \mathrm{bmt}$ & 41. & 161 & $\begin{array}{l}\text { National emissions allowed at a lower level, } \\
195 \text { bmt and costs would be slightly higher: } \\
\text { Not a pure cap and trade as it includes other } \\
\text { policies as well }\end{array}$ & \\
\hline Kerry-Snowe (2007) & $\begin{array}{l}\text { Between } 203 \text { and } \\
167 \text { bmt }\end{array}$ & $\sim 47$ & -141 & $\begin{array}{l}\text { Calculated as halfway between Feinstein } \\
(2007) \text { and Sanders-Boxer ( } 2007) \text {. Would } \\
\text { result in a reduction of emissions to } \\
65 \text { percent below } 1990 \text { levels by } 2050\end{array}$ & \\
\hline Sanders-Boxer (2007) & $167 \mathrm{bmt}$ & 53 & 210 & $\begin{array}{l}\text { Requires a reduction in emissions of } \\
80 \text { percent below } 1990 \text { levels by } 2050 \text { and } \\
\text { does not include other features (e.g. efficiency } \\
\text { standards, renewable portfolio requirements) }\end{array}$ & \\
\hline $\begin{array}{l}\text { Waxman-Markey } \\
(2007)\end{array}$ & $148 \mathrm{bmt}$ & & & $\begin{array}{l}\text { Most stringent reductions in emissions } \\
\text { resulting in the highest costs }\end{array}$ & $\begin{array}{r}\text { Table I. } \\
\text { Summary of recent US }\end{array}$ \\
\hline \multicolumn{5}{|c|}{ Source: Paltsev et al. (2007) } & Congressional proposals \\
\hline
\end{tabular}

shows that this tax ranges from a low of $\$ 7$ per ton in 2015 to $\$ 210$ in 2050 for the more aggressive bills. It has been estimated that current greenhouse gas emissions are now about 15 percent higher than 1990 levels. Thus, the latter set of bills involve very aggressive and extreme reductions in greenhouse gas emissions.

However, the stalemate in the US Congress has not halted efforts to implement some form of cap and trade. As noted earlier, the EPA has established rules to limit emissions by coal-burning power plants as they have been able to do this through a 2007 directive from the Supreme Court. In Massachusetts v. Environmental Protection Agency (549 US 497, 2007), the court ruled that the EPA had the power to bypass Congress and regulate greenhouse gasses on its own initiative under the Clean Air Act and furthermore, again in 2011, in American Electric Power Co. v. Connecticut (564 US 323,2011 ), the court stated that the Clean Air Act gives the EPA the lone authority to regulate the emission of greenhouse gasses. The ramifications of these rulings are still unclear as the EPA has thus far refrained from implementing any cap-and-trade systems, however, critics predict that these rules will ultimately increase the price of energy generated by coal-burning power plants and essentially make new coal plants extinct (Barringer, 2012).

Intuitively, more aggressive bills would also tend to produce more federal revenues in terms of sales of carbon credits. A recent study by the Massachusetts Institute of Technology (MIT) joint program on the science and policy of global change suggested that under the more aggressive second set of bills, that the system could generate 
federal revenues between $\$ 100$ and $\$ 500$ billion per year, possibly bringing in close to 20 percent of total federal tax revenues (Paltsev et al., 2007).

The proposals presented above are all national initiatives to establish a market to trade and control emissions. In addition to these, there are also those that have been organized regionally. One of these, RIGGI, or the (Regional Greenhouse Gas Initiative, 2012) is a 501(c)3 cooperative effort operating in nine states - Connecticut, Maine, Maryland, Massachusetts, New Hampshire, New York, Rhode Island and Vermont with the purpose of reducing greenhouse gas emissions (www.riggi.org). They have set a goal to cap and reduce power sector $\mathrm{CO}_{2}$ emissions by 10 percent by 2018 by establishing $\mathrm{CO}_{2}$ Budget Trading Programs in each state and facilitate a regional auction for $\mathrm{CO}_{2}$ allowances. RGGI has received some positive feedback from environmentalists as they represent the "first mandatory, market-based $\mathrm{CO}_{2}$ emissions program" in the USA, touting a sale of 24.5 million $\mathrm{CO}_{2}$ allowances at a recent auction (www.riggi.org).

\section{Potential impact on US business}

Obviously, depending on whether other revenue sources and tax rates are adjusted, or reduced, to take into consideration this increased revenue source would represent a great increase in what would essentially be a tax on American business and consumers. We tend to define this as a hidden tax, as a form of higher prices and energy costs. Certainly it is a question of what effect this would have on economic growth as US taxes would essentially be raised by potentially up to approximately 20 percent over their present level. The US Treasury Department made an estimate that the Waxman-Markey bill would cost American taxpayers about $\$ 393$ billion per year and according to the Heritage Foundation, cap and trade would cost $\$ 4$ trillion by 2035 and would only reduce temperature by $0.2^{\circ} \mathrm{F}$ (Terrell, 2010). Other researchers agree that the impact would be "exceedingly small" in terms of the reductions of $\mathrm{CO}_{2}$ levels (in the range of $23-25$ parts per million (ppm)) and an overall decrease in projected increases in global warming that is "scientifically meaningless" (World Climate Report, 2007).

Proponents dispute this and they suggest that if the additional revenues are invested in alternative energy sources, such as geothermal or wind power, that this can produce countervailing savings in energy costs to offset this tax. Additionally, there has been a trend among environmentalists to consider the construction of additional nuclear power plants, as these were increasingly seen as a "green" energy source rather than merely as a potential hazard.

Other effects of these cap-and-trade policies have also been studied. According to the MIT study, the caps on $\mathrm{CO}_{2}$-e would have a direct effect on the price of gasoline by adding more than $\$ 2.00$ a gallon for levels at $167 \mathrm{bmt}$ and $\$ 0.70$ per gallon at an allowance of $287 \mathrm{bmt}$ (Paltsev et al., 2007). This is a hidden tax, but nonetheless would be crippling to the recovering economy. In addition, the effect on annual US GDP has been estimated under the Liberman-McCain restrictions (which by far is not the most aggressive), to be 1.1-3.2 percent ( $\$ 457-\$ 1,332$ billion) lower by the year 2050 (World Climate Report, 2007).

Less aggressive emissions trading proposals would not result in similar high levels of increased revenues and economic impact. The same MIT study suggests that by 2050 , under less aggressive proposals, carbon dioxide emissions prices would rise to no more than $\$ 39$ per ton, or only to about $20-25$ percent of the potential prices under the 
nore aggressive proposals. This would also of course, mean a much lower hidden tax on the American consumer, but as a counterpoint, also result in less money available for investment in renewable energy sources.

As these proposals are considered and the impact on business weighed, one cannot ignore results experienced from the cap-and-trade regulations for sulfur dioxide enissions on the utility industry. As previously discussed, this program to curb the effects of "acid rain" in the 1970s has been used as the model for establishing a program to reduce $\mathrm{CO}_{2}$ emissions and was originally predicted to have a negative impact on US businesses. For many years, the acid rain program worked as it was originally planned and levels of sulfur dioxide were reduced and the market was selling allowances in the range of $\$ 400-\$ 500$ in early 2000 . However, in 2005, the EPA decided to increase regulation and expand the program to eight additional states resulting in the allowances to sell for over $\$ 1,600$. This resulted in lawsuits against the EPA, which in turn made the program a "cap" only, resulting in a collapse of the "trade" component as the price of the allowances plummeted to $\$ 3$ or less in 2010 (Peters, 2010). Industry observers had considered this program "a success, helping to reduce sulfur dioxide emissions by half" (Peters, 2010) but given the increased EPA regulations, the allowances are now worthless. It is unfortunate that the USA can no longer look to this model to help shape future energy policy, but this experience provides further evidence of the effect of government intervention on free markets.

\section{Global disappointment as other nations move on}

The battle in the US Congress had an audience that was much broader than just domestic observers. Climate change and global warming are issues that have been discussed and dealt with on a world stage for several years. While the US Senate had tabled any type of legislation to deal with greenhouse gas emissions, David Cameron, the British Prime Minister announced at the European Commission that new taxes would be proposed on the heaviest emitters of greenhouse gasses so as to promote cleaner technologies like nuclear power and biofuels (Kanter, 2010). However, the tax that the European Commission discussed in Brussels goes beyond that proposed in the USA in that it would also affect individuals who burn fossil fuels to drive their cars and heat their homes. A major supporter of this proposed bill was former President Nicolas Sarkozy of France, who tried to impose similar measures. Only Denmark, Finland, and Sweden have such taxes already in place (Kanter, 2010).

Phase I of implementing the Kyoto Protocol in Europe began in 2005, and virtually all European Union states continue to participate. This phase primarily limits the amount of carbon dioxide emissions from large users, including utilities and large factories. While this would appear to be a limited benefit, actually the estimate is that these limits would apply to almost half of all European Union carbon dioxide emissions. In a 2008 study, the European Union efforts were expected to reverse a projected annual increase of 1-2 percent per year in greenhouse gas emissions into an actual decline, albeit a small one (Grubb et al., 2009). As an interesting side point, it was found that early levels of emission caps were not tight enough to result in significant reduction in emissions, and that in fact the total allowances did not exceed the actual emissions. Thus, it functioned essentially as a voluntary cap in the early years, as the mere existence of a goal, and its statement of a government commitment to emissions reductions, was causing meaningful reductions in greenhouse gas emissions even when the caps were not low 
enough to actually mandate reductions. It also resulted in the price for carbon credits to be extremely low or nonexistent in the early years, as businesses simply did not need to purchase them.

As phase II of the Kyoto Protocol was implemented, it was estimated that this should result in emissions reductions in 2010 of about 2.4 percent, as compared to what they would have been without the cap. This was expected to be the first meaningful legally mandated reduction, and to begin to create a market for carbon credits. Phase III is due to be implemented between the years of 2013 and 2020 (Jones et al., 2007). In spite of this, the European Commission proposal pushes for a number of changes, including setting an overall European Union cap, with the allowances being allocated to the individual European Union member countries. It will also, of course, include tighter limits on the use of offsets, and a move from the sale of allowances, to the auctioning of allowances. The goal is to achieve a reduction in greenhouse gas emissions of 30 percent below 1990 levels by the year 2020 which would be a significant reduction.

\section{The current status}

In the current rounds of talks, the USA may no longer be the only holdout. The USA has never ratified the Kyoto Protocol; Canada has since withdrawn, Japan and Russia have stated that they will not accept future targets, and Australia, New Zealand, and the Ukraine have not stated what their positions will be in the future (Morales, 2012). Otherwise, the world is divided with underdeveloped countries, along with newly emerging manufacturing economies in South and East Asia, still exempted from the Kyoto Protocol requirements and emissions trading proposals. Ironically, this still includes India and China, the two fastest-growing large manufacturing economies today, and two of the fastest-growing economies overall. At the other end, developed European Union countries are showing a strong commitment to the Kyoto Protocol, and to emissions trading systems, and forging strongly ahead.

While the USA continues to delay in pursuing cap and trade, other voices in the USA criticized the current cap-and-trade proposals as actually being insufficient. One scientist opined that what is really required is measures that amount to "[...] nothing less than a reorganization of society and technology that will leave most remaining fossil fuels safely underground" (Lohmann, 2007). According to the group Carbon Trade Watch, carbon trading has a poor track record. European Union efforts have also been criticized as insufficient and at times, to support politically favored projects inappropriately.

As suggested above, much of the US criticism of cap and trade, and to some extent in other countries, is now actually coming from those who believe it does not go far enough. Recently, both the well-known conservative American Enterprise Institute, as well as the liberal Brookings Institution, produced a bipartisan suggestion that the USA consider going full bore toward renewable energy instead. The bipartisan proposal recommended a $\$ 25$ billion investment in clean energy research by the US Energy Department (Hayward et al.,2009) and suggested that it is wrong to present this situation as a choice between global warming or mandating widespread adoption of renewable energy. It also suggests that the choices have to include the consideration of an economy being severely hurt by expensive alternatives to fossil fuel or costly emissions control devices. Instead, the bipartisan proposal suggests that the USA embark on a policy of greatly increased building of nuclear power plants, and the end of government subsidies for any forms of energy that do not improve efficiency (ending subsidies for fossil fuels). 
The current US mood is that proposals to reduce greenhouse gas emissions will be expensive and burdensome to US businesses and consumers. In fact at the present time this is basically what is preventing them from going forward. However, at the same time, thoughtful proponents of the environment are actually coming out with more cost effective and less economically burdensome proposals. The bipartisan proposal described previously is simply one of these. Even $\mathrm{Al}$ Gore, although a strong cap-and-trade proponent, is currently working with others to produce alternatives that lower the cost of emissions reduction. Importantly, the consensus is now growing that in order to achieve the goals of cap and trade, proposals will have to be expanded internationally, and include India, China and other emerging manufacturing economies. If this can be done, it appears that cap and trade will continue to be part of the landscape of US emission reductions, along with the increasing use of alternative and other renewable energy resources.

The USA could learn much from the countries that have already adopted and implemented initiatives involving cap-and-trade systems. For that reason, we should focus our research efforts on their experiences, analyzing not only the environmental impact, but the effect that these countries have realized on their general overall economy, and on individual businesses as well. This could be accomplished by examining trends in gross domestic product before and after the implementation of these programs as well as analyzing individual businesses and industry sector profitability under these programs. Perhaps, with this additional evidence, we can make a more informed decision as to how the USA should move forward toward these initiatives.

\section{References}

American Electric Power Co. v. Connecticut (2011), 564 US 323.

Barringer, F. (2012), "For new generation of power plants, a new emission rule from the EPA", The New York Times, 27 March.

Broder, J.M. (2009), "House passes bill to address threat to climate change", The New York Times, 27 June, pp. 1-3.

Broder, J.M. (2010), "Cap and trade loses its standing as energy policy of choice", The New York Times, 25 March, pp. 1-5.

Center for American Progress (2008), "Cap and trade 101, what is cap and trade, and how can we implement it successfully?", 16 January.

EPA (2012), Acid Rain Program, Environmental Protection Agency, available at: www.epa.gov; www.epa.gov/airmarkets/progsregs/arp/basichtml (accessed October 30, 2012).

EPA (2010), Acid Rain Program $\mathrm{SO}_{2}$ Allowances Fact Sheet, Environmental Protection Agency, available at: www.epa.gov.airmarkets/traing/factsheet (accessed September 8, 2010).

Greenblatt, A. (2010), "How cap and trade was "trashed", 26 April, available at: www.npr.org/ templates/story/story.php?storyld $=126280761$

Grubb, M., Thomas, L., Brewer, M.S., Robert, H. and Dora, F. (2009), "Climate policy and industrial competitiveness: ten insights from Europe on the EU emissions trading system", Climate Strategies, 3 August, available at: www.climatestrategies.org/our-reports/ category/17/204.htm

Hayward, S.F., Mark, M., Ted, N. and Michael, S. (2009), Post-partisan Power: How a Limited and Direct Approach to Energy Innovation Can Deliver Clean, Cheap Energy, Economic Productivity and National Prosperity, available at: www.guardian.co.uk/environment/ 2009/sep/15/europe-us-copenhagen; www.politico.com/static/PPM170_101012_post partisan.html 
Houghton, F., Girggs, Noguer and IPCC Report (1997), Implications of Proposed $\mathrm{CO}_{2}$ Emissions Limitations, October, available at: www.IPCC.ch, For a history of the IPCC, available at: www.ipcc.ch/organization/organization_history.htm

Jaffe, J., Matthew, R. and Robert, N.S. (2009), "Linking tradable permit systems: a key element of emerging international climate policy architecture", Ecology Law Quarterly, Vol. 36, pp. 789-808.

Jones, B., Keen, M., Norregaard, J. and Strand, J. (2007), "Appendix 1.2, climate change: economic impact and policy responses, Chapter 1. Global prospects and policy issues. World Economic and Financial Surveys", World Economic Outlook, Globalization and Inequality, IMF, October, available at: www.imf.org/external/pubs/ft/weo/2007/02/ (accessed April 26, 2010).

Kanter, J. (2010), "Europe considers new taxes to promote 'clean' energy", The New York Times, 22 June, pp. 1-3.

Kyoto Protocol (2012), As Detailed by the United Nations Framework Convention on Climate Change, UNFCCC, available at: http://unfccc.int/kyoto_protocol/items/2830.php (accessed October 18, 2012).

Lohmann, L. (2007), "Carrying on polluting by synthesis/regeneration", Vol. 43, Spring, from an earlier version appearing in New Scientist, available at: www.greens.org/s-r/43/43-07.html (accessed December 2, 2006)

Massachusetts v. Environmental Protection Agency (2007), 549 US 497.

Morales, A. (2012), "Climate deadlock breaks as slow UN talks frustrate US, EU", Bloomberg Businessweek, 25 May.

Paltsev, S., Reilly, J.M., Jacoby, H.D., Gurgel, A.C., Metcalf, G.E., Sokolov, A.P. and Holak, J.F. (2007), "Assessment of US cap-and-trade proposals", Report No. 146, MIT Joint Program on the Science and Policy of Global Change, April.

Peters, M. (2010), "Changes choke cap-and-trade market", The Wall Street Joumal, 12 July.

Regional Greenhouse Gas Initiative (2012), available at: www.rggi.org (accessed October 3, 2012).

Resources for the Future Foundation (2012), Understanding Current Policy Proposals, available at: www.rff.org/Publications/Pages/CPF_Current_Policy_Proposals.aspx (accessed October 18, 2012).

Terrell, R. (2010), "Cap-and-trade con", The New American, 21 June, pp. 17-20.

Tietenberg, T. (2003), "The tradable-permits approach to protecting the commons: lessons for climate change", Oxford Review of Economic Policy, Vol. 19 No. 3, pp. 400-419.

World Climate Report (2007), The Big Secret: Climate Bills Result in No Meaningful Impact on Global Temperature, November, available at: http:/worldclimatereport.com

Corresponding author

Heidi Hylton Meier can be contacted at: h.meier@csuohio.edu 